\title{
“DISPERSED” PUBLIC AUTHORITY IN LABOUR LAW: SYSTEMATIC DILEMMAS IN LAW CONTINUED
}

\begin{abstract}
The doctrinal discussion on personal data protection regulated by the EU regulation, i.e. the GDPR, appears to re-create a vibrant and never-ending debate on the private law nature of the employer who does not implement the principle of freedom of contract when concluding a contract of employment. Because it is simply an entity pursuing public interests. The social labour inspector is a prototype of data protection officer in the field of labour law. As a matter of fact, he is also executing this "dispersed" public authority in labour law.
\end{abstract}

Słowa kluczowe: władza publiczna, prawo publiczne/prywatne, rozproszona władza publiczna

Keywords: public authority, public/privite law, dispersed public authority

ASJC: 3308, JEL: K31

It has only been a couple of years since the Polish doctrine of labour law started revealing some symptoms of a genuine academic discourse, meaning it no longer treats labour law as a branch alienated both from the social and economic life and the legal system as such. For it is my distinct impression that a large part of scholarly discussion in Polish labour law tends to disregard a totally fundamental issue, namely the fact that labour law is an integral part of the law system, along with a more general one that boils down to a statement that the law is simply a discourse about life; I would like to add here that labour law is a genuinely fundamental part of this discourse about life. The topic of "dispersed" public authority that has been recently addressed in literature seems to be such a symptom of a genuine academic discourse in labour law. However, what I would like to focus on primarily in the present article is a discussion on whether we may talk of any "dispersed" public authority in labour law at all.

I. The issue of "dispersed" public authority in the labour law science has emerged in the discussion on the GDPR. Actually, it has been addressed by one Author, namely Arkadiusz Sobczyk. In his book entitled "GDPR. Dispersed public authority" (Sobczyk 2019) this author carries out a comprehensive analysis of regulations set forth in Regulation (2016/679) of the European Parliament and of the Council of 27 April 2016 
on the protection of natural persons with regard to the processing of personal data and on the free movement of such data, and repealing Directive 95/46/CE (hereinafter: the General Data Protection Regulation $)^{1}$ and reflects, in the most natural way, upon the problem of personal data protection in labour law, and he actually goes even further than that as he moves on to discuss the right to privacy in labour law. As he states, the underlying thesis of his book is that ,with a couple of exceptions only, the GDPR remains the domain of administrative law, regulating the issue of competence to execute public authority and other public tasks" (Sobczyk 2019, p. 13) According to this Author: "Considering that the GDPR allows for a massive interference in informational autonomy of an individual by private entities, what we are dealing with here is one of the most common cases of dispersed public authority" (Sobczyk 2019, p. 138). Given the fact that the employer carries out the "acts" of collecting employees' personal data as well, this statement pertains to labour law to a certain extent. I wrote "to a certain extent" in the previous sentence, because, as Arkadiusz Sobczyk proves in his entire study, through the definition of the controller (as a result of which, the said Regulation does not apply to the "circulation" of personal data in many cases), the GDPR cannot apply to a whole range of situations where the employer performs data collection, fulfilling their legal obligation to collect specific data under the law and as it is legally appropriate in a given case. Notabene, what I consider to be an extremely valuable fragment of the monograph in question is the one in which Arkadiusz Sobczyk distinguishes different layers of personal data protection, beginning from the most baseline one, namely private non-business relationships, and then moving on to relationships with business entities or entities performing public functions or positions of trust. He makes a very accurate wrap-up of his deliberations, when stating the following:

Whereas in cases described above as levels I-VI, personal data is transmitted by the will of data subject or collected only because the state has ordered to do so, it would be hard to consider the above safeguarding measures as insufficient. What is more, if the GDPR was to be applied in the aforementioned cases, it would involve a disproportionate burden of obligations and legal risks for the entity that must process data or performs the said processing in the extent that has not been determined on their own (Sobczyk 2019, pp. 58-59).

Thus, in this single sentence supported by a detailed, multi-page discussion and illustrated with a whole range of meaningful examples, the Author has substantially structured the space of debate on personal data protection, in particular the one triggered by the entry into force of the GDPR. It is enough to mention the scale of misunderstandings concerning personal data protection held by persons who consider themselves "professionals" in this topic area. I listened to their speeches during a conference organised at the Faculty of Law and Administration of the Jagiellonian University on 11-12 May 2019, where the idea that data protection officer "may be" an entity from the sphere of

\footnotetext{
1 To make it shorter, I will also use the term: GDPR.
} 
public law could not find proper recognition in their debate. In a nutshell, the aforementioned Author deserves credit for the thesis that is fundamental for personal data protection in the light of the GDPR and is expressed in the following words: "the GDPR applies only if the domestic legislation so provides through the indications of the personal data controller" (Sobczyk 2019, p. 57).

Coming back to the connection between the GDPR and aspects of labour law made by Arkadiusz Sobczyk, I must first note that this Author, apart from pointing out that the definition of a controller excludes employers from the scope of the GDPR in many instances, as I have already mentioned, recognises how important for labour law is the basis for data processing referred to in Art. $6 \$ 1$ letter $\mathrm{f}$ of the GDPR (it sets forth that processing is lawful, only if it is necessary for the purposes of the legitimate interests pursued by the controller or by a third party, except where such interests are overridden by the interests or fundamental rights and freedoms of the data subject which require protection of personal data, in particular where the data subject is a child). He is right in his conclusion that

... assuming that personal data controller is an employer understood as a synonym of an entrepreneur, their legitimate interest (understood as a realisation of their personal dignity through business activity) and such legitimate interest pursued by third parties, i.e. employees (understood as a realisation of their dignity through work), coincide (Sobczyk 2019, p. 179).

However, I think that from the perspective of labour law there is a huge potential in the basis for lawful data processing set forth in the provisions of Art. $6 \$ 1$ letter $\mathrm{c}$ of the said Regulation, where it is stated that personal data processing shall be lawful only if it is necessary for compliance with a legal obligation to which the controller is subject. “Therefore, I doubt if it is really the case that: „Art. $6 \$ 1$ letter $c$ is a regulation addressed first and foremost to the state" (Sobczyk 2019, p. 159), as Arkadiusz Sobczyk wrote. His discussion of the data protection officer, namely as regards the placement of this entity in the sphere of labour law, is truly inspiring for the labour law science in the context of the concept of public authority in employment relationships. As you may guess, it is at fragment of a broader concept of state (public administration) interference in employment relationships. Here Arkadiusz Sobczyk categorically claims that: "contrary to many views expressed in literature ... he [data protection officer-A.M.] is not a private advisor of the controller" (Sobczyk 2019, p. 2010).

Having this in mind and referring to my observation that the topic of "dispersed" public authority addressed in literature appears to be such a symptom of a genuine scholarly discourse in labour law, I would like to say that this is exactly the case with the monograph by Arkadiusz Sobczyk; it means that his discussion of "dispersed" public authority in the context of labour law allows to assert that we are finally seeing an approach to labour law science which does not remove the labour law from the legal system, and perceives this law as a key element of the social and economic order, while striving to position this law accurately amongst other branches of the law. The 
Author, Arkadiusz Sobczyk, begins from discussing the topic of personal data protection in genere, yet he does not lose sight of personal data protection in labour law, being a fragment thereof. He does not adopt an insider perspective to the latter, i.e. personal data protection in labour law; instead, he views it from the perspective of the system as a whole. And that is what makes the monograph by Arkadiusz Sobczyk stand out among those we "deal with" on a daily basis, i.e. where a given legal phenomenon is being presented in a certain legal and doctrinal isolation. I shall only add that when analysing personal data protection in a comprehensive way, the Author gives particular attention to labour law issues whenever they emerge, which is hardly surprising. Actually, he deserves credit for his contribution to the development of the doctrine of the discipline he represents.

II. Nevertheless, as I have already mentioned, I would like to focus on the topic of "dispersed" public authority addressed by Arkadiusz Sobczyk, as it can be found in the labour law; yet, I think it is plausible in a smaller extent than it is presented in analyses made by Arkadiusz Sobczyk. However, the above statement pertaining to the concept of "dispersed" public authority in labour law fits perfectly in the constant dilemma whether labour law should be classified as private or public law; in my opinion, this dilemma is apparent.

As I have already pointed out in the above passage, according to Arkadiusz Sobczyk's arguments, the "dispersed" public authority may be, and actually is, exercised by data controller; what follows, such authority must be exercised by the employer, as well (as he turns out to be the controller). As I have already quoted, Arkadiusz Sobczyk wrote that:

Given the fact that the GDPR allows private entities to interfere massively with an entity's information autonomy, what we are dealing here with is one of the most widespread cases of dispersion of public authority (Sobczyk 2019, p. 138).

He goes on to add:

Due to the fact that 'private' data controllers are considered bodies performing public tasks, they are under the obligation, within the scope of the authority thus exercised, to apply constitutional axiology, where the controller's interest must give way to the public interest (Sobczyk 2019, p. 138).

This conclusion is preceded by a very detailed discussion, where he states that:

. . the GDPR is a legal act that decentralises powers to exercise public authority. In the case of a centralised model, any entity having an interest in accessing personal data, i.e. having in fact an interest in interfering with someone else's right to privacy and informational autonomy, should have applied to a state authority to have this right granted by way of an act of authority. In the meantime, the GDPR allows the entity concerned to issue such a decision (administrative act) by itself. Nevertheless, it remains a public activity subject to public scrutiny, with a complaint being a typical control tool in place (Sobczyk 2019, p. 102). 
Without a doubt, it must be stated that Arkadiusz Sobczyk very accurately noted that there is indeed a significant similarity between the axiology of data collection and processing found in the Constitution and in the GDPR. The Author rightly stated that the rules and principles of personal data processing set forth in Art. 5 of the GDPR "are nothing but a definition of the operating principles of public authority in a state governed by the rule of law, in particular in the context of freedom and liberty rights" (Sobczyk 2019, p. 75). ${ }^{2}$ Then he noted rightly that it is a different wording of regulations provided for in Art. 7, $31 \S \$ 3,47$ and 51 of the Constitution of the Republic of Poland. However, I have doubts as whether the mere fact of "using" or "applying" the constitutional axiology by a private entity when interfering with privacy, which is an interest protected by law (I believe that it is not quite possible to interfere with the right to privacy itself, as this interference can only be related to an interest protected by law), makes this entity a public authority by reason of the performance of a public task.

I think it is not the case.

First of all, I cannot see how personal data "management" can be classified as a public task. Data protection is regulated by the state through its legislative power. The issue of public tasks is a mental concept from the operating sphere of the executive power only. Nevertheless, this remains a side issue. For what constitutes a particularly intriguing "moment" in Arkadiusz Sobczyk's arguments is the "effect" of the connection he makes between "using" the constitutional axiology in applying the law and the "type" of entities (private law entities, to be precise), which boils down to assigning data controllers a public law status in each and every case; as this Author mentioned many times in his monograph, that is exactly the way these entities exercise public authority. I think that any discussion with Arkadiusz Sobczyk on this should start with an analysis of relevant constitutional provisions on the right to privacy, which define their material scope.

Indeed, what I agree with Arkadiusz Sobczyk on is that the informational autonomy guaranteed by Art. 51 of the Constitution to a certain extent applies only to obligations of public authorities (Sobczyk 2019, pp. 21, 77). However, it does not mean that such protection is not available to the individual at all in horizontal relations, as it could be concluded from Art. 51 by way of argumentum a contrario. That is because in the literature we can read that: "The basis for constructing such protection is then Art. 47." What follows is that:

Safeguards proclaimed in this provision grant protection to individuals to an extent not covered by other regulations, relating either to autonomy as such (the ability to decide on one's personal life) or its preconditions (Wild 2016, p. 1173). ${ }^{3}$

${ }^{2}$ I am aware of the contents referred to by the Author when he quotes Niżnik-Dobosz 2017, pp. 79-80.

3 As it has been brilliantly noted in literature, the fact that Art. $51 \S 2$ imposes limitations on public authorities in the way they administer information about citizens does not mean that any administration of information about other persons is unrestricted nor that any management of information about individuals by entities other than public authorities may be performed in an unlimited manner. However, in 
In a nutshell, the legal norm resulting from the provisions of Art. $51 \S 1$ of the Constitution of the Republic of Poland does not safeguard an individual against any breaches of informational autonomy in horizontal relations, in particular in contractual relations. Safeguards against such interferences shall be sought in Art. 47 of the Constitution.

Given that data controllers, and thus in some cases employers, are private law entities, provisions of Art. 47 of the Constitution shall apply. And this article is essential for determining whether the GDPR is in the domain of private law or public law. This provision reads as follows: "Everyone shall have the right to legal protection of his private and family life, of his honour and good reputation and to make decisions about his personal life." What should be noted here is that the individual's rights under this provision are not limited to having public authority refrain from any interference in the sphere of private life; above all, the individual may demand that public authority ensures effective protection of values defined in the said provision. It has been secured by the GDPR, where the underlying aim is to ensure that a certain interest, namely the privacy, is safeguarded. In other words, it is the duty of public authority to provide the individual with genuine remedies to safeguard him or her against any breach of interests defined in Art. 47. Public authorities are first and foremost obliged to avoid privacy hazards; from the constitutional perspective, it is flawed to tolerate threats to individual privacy (Wild 2016, p. 1174). The need for effective protection of privacy as a human right has simply forced the state to regulate data collection in social and business transactions. At the same time, what is crucial here is that the effort aimed at enhancing the effectiveness of privacy protection in horizontal relations does not have to deprive the data recipient of the private law quality. After all, from the point of view of the political system of the state it is not about expanding the state empire, but about focusing on building the freedom and strength of many independent entities.

I think that the actual and proper key to understand the discussed doubts is a view presented in literature that different rules apply to defining the scope of permitted interference of public authority in interests protected by law that are defined in Art. 47 of the Constitution of the Republic of Poland than to defining the scope of positive duties of the state aimed at ensuring effective protection in horizontal relations. As we can read in literature:

In any relations with public authorities, Art. 47 should be treated as a principle, with exceptions from this principle being allowed only if they meet the requirements set forth in Art. $31 \S 3$ of the Constitution of the Republic of Poland. Where constitutional rights of two equivalent entities collide, they must be balanced according to less formalised rules (Wild 2016, p. 1174).

And why is "this" rule governing horizontal relations de facto applicable to relations in personal data protection?

both cases the constitutional standard should not be derived from Art. 51, but from Art. 47. These articles safeguard the same constitutional value (Wild 2016, p. 1222). 
The reason behind it is that the principle of human freedom is a principle of the state's political system. It is cited in the Preamble to the Constitution of the Republic of Poland, where one can read that "the respect for freedom is the unshakeable foundation of the Republic of Poland," but most of all it is presented in the provisions of Art. $31 \$ \$ 1$ and 2 of the Constitution of the Republic of Poland. As the literature suggests, these provisions should be the grounds for formulating a thesis that due to the fact that the principle of human freedom has been expressed before the principle of equality, and it gives way to the guarantee of human dignity only, it follows that, in principle, subjects of law may enjoy this freedom and so arrange their legal relationships, in particular obligation relationships, as they consider appropriate, without having to give other persons or institutions the powers specified in the Constitution (Bosek 2016, p. 762). As a result, from the perspective of human freedom, what should be brought up first is the principle of freedom of contract. It has been excellently pointed out by the Constitutional Tribunal in its ruling, where one can read that the fundamental principle of functioning of free individuals is the principle of freedom of contract; in other words, the principle of freedom of contract shall be first and foremost considered in terms of individual freedom. ${ }^{4}$

Based on the above, it could be argued that any legal restrictions of the freedom of contracts of obligation shall be viewed as inconsistent with the abstract constitutional principle of protection of human freedom. The aspect of non-recognition of the principle of freedom of formulating the contents and the purpose of the contract outside the scope of obligation relationships should then be given strong consideration. However, it is both possible and acceptable to have the principle of freedom of contract derogated in the public interest. This is what happened in the field of property, family and inheritance law (Drozd 1990, p. 256; Skowrońska-Bocian 2003, p. 1; Niedośpiał 2004, pp. 91-93). The situation is similar in labour law; yet, the doctrine of labour law cannot "understand" it and insists on the principle of freedom of contract in labour law. Thus, given the fact that the starting point for any legal regulations is human, free and enjoying the natural and inalienable dignity, the principle of freedom of contract is a rule. It does not mean that there are no exceptions to this rule, though. There are branches of private law that refuse to recognise the above, and thus the legislator introduces mandatory provisions in the name of protecting other interests that contribute to public order. And that is what happened in the case of regulation of personal data protection covered by the GDPR.

${ }^{4}$ Ruling of the Constitutional Tribunal of 29 April 2003, SK 24/02, OTK-A 2003, No. 4, item 33. To put it simply, the obligation to respect human freedom, which is derived from Art. $31 \S 2$ sentence 1 of the Constitution, applies not only to the relationship of man and citizen with the state and public authorities, but also to relationships between individuals themselves; the above provisions set forth in the most complete way that no one may be forced to conclude a contract or forbidden to conclude a contract, nor forced to choose a particular contractor, nor forced to include any specific provisions into the contract, unless otherwise provided by the law. What is more, this restriction affects everyone equally; in turn, this understanding of freedom, being obviously just a "small part" of the entire sphere of human freedom, is safeguarded in the constitution. 
So what exactly has "happened"?

It has been asserted that whenever a given entity (either natural or legal person, public authority, individual or any other entity), independently or jointly with others, determines the purposes and means of personal data processing, they must follow the guidelines of the EU legislator; at this point, a reference should be made to the provisions of Art. $5 \$ 1$ letter a of the GDPR, according to which data shall be processed lawfully, fairly and in a transparent manner in relation to the data subject, as well as all provisions of the GDPR pertaining to the rules and principles of data processing, such as purpose limitation, data minimisation or accuracy and storage limitation.

One may ask why has the legislator interfered in the principle of freedom of contract between data subject and recipient, hence what has actually justified the issuance of such an extensive legal regulation at the EU level?

Well, as Arkadiusz Sobczyk rightly pointed out, it was about the human right to privacy, and more precisely about the actual realisation of this right (Sobczyk 2019, p. 19). What is interesting, and what is responsible the "depth" of this legislation in my opinion, is that the EU legislator did not rely on sharp concepts for this interference in the principle of freedom of contract. And he had to do so, because it is the entity using this data in business transactions that is supposed to assess the degree and extent to which they "need" this data for "business" purposes. And rightly so. In fact, there was no other way to go about it, as there was the need to boost the effectiveness of the individual's right to privacy on one hand, and the need to safeguard the right to business activity on the other hand, which is so essential for the economic development of any community.

Having this in mind and referring to the topic of "dispersed" public authority, I do not quite support the view that data controller can be perceived as public authority. Rather, if we were to stick to the nomenclature of concepts proposed by Arkadiusz Sobczyk, I think it is absolutely justified to identify a growing "dispersion" of public interests in private law.

I am aware of the views expressed on many occasions that too many burdens are placed on private entities (here: data controllers), as these entities are now obliged by law to constantly "weigh" interests. This approach does not surprise me at all, as Polish legal culture is characterised by a rather low level of discourse. And this is mainly because it takes expertise, sensitivity and, most of all, courage to "weigh" interests. The Polish milieu of law practitioners is in fact comprised of many "captive minds." Yet, they should not be resented that much, because this captivity originates in the science of law (I am mainly thinking about the science of labour law, which is actually often created by these practitioners). The conformity of thinking stems from the science, and this conformity will never help bring out an individual interpretation, albeit one based on the law and within the limits of the law. Therefore, I am absolutely not surprised by the overwhelming lack of understanding for the legal regulation of personal data protection introduced by an EU regulation, i.e. the GDPR; however, knowing the cultural environment of Polish law practitioners, I can imagine how they would fear the task of "weighing" interests in the context of treating data controller as a private law entity. 
Coming back to the topic of "dispersed" public authority, I believe that this concept perfectly reflects the essence of the effort of data protection officer, being an institution presented in much detail in the study by Arkadiusz Sobczyk. That is because the legislator, being aware of the obligations imposed on private entities to protect the legal interest of privacy and knowing that these obligations are quite complex, as they require interests to be "weighed," does not leave them (these entities) alone, so to speak. The legislator has introduced the institution of a data protection officer. In fact, this officer is not a public authority, but a public administration body in a functional sense (i.e. including entities with and without administrative authority). I am writing the above in the light of well-established expertise of administrative law. Indeed, if I was to be less precise, I could write that the whole administration in a functional sense is public authority; yet, then you would have to keep it in mind that not all entities within the domain of functional public administration benefit from the state empire. For this reason, it is great that Arkadiusz Sobczyk so clearly determined the legal nature of data protection officer in his discourse. It is absolutely necessary to quote the following statements of this Author, where he writes: “. . the appointment of DPO is nothing but granting the designated person a public status with public powers ..." (Sobczyk 2019, p. 209). And he adds: "... DPO performs his work in the public interest, works for the state (society) and is both directly and indirectly supported by the state" (Sobczyk 2019, p. 215). What I consider to be absolutely important is the fragment of the discussion of Arkadiusz Sobczyk on the subject matter that addresses the understanding of the function of data protection officer as a position of trust (Sobczyk 2019, p. 235).

I believe that the recognition of data protection officers as "dispersed" public authority bodies reflects, in a very interesting way, a larger Polish problem, namely denying the public law character to many subjects of law performing public tasks. Again, it does not surprise me in the context of the Polish legal culture, where the public law status of social labour officer is being questioned, despite the fact that this institution is very well established in labour law. Coming back to systematic approach to personal data protection under the GDPR: the institution of data protection officer undoubtedly completes the EU concept of regulating this in a wonderful way. This is because data controller "receives" professional assistance from the state, which indeed has a public task, but when it comes to ensuring real conditions for effective personal data protection. Surely, this controller (private entity) will have to bear the costs of appointing data protection officer, but will be exempted from liability to a certain extent.

The doctrinal discussion on personal data protection regulated by the EU regulation, i.e. the GDPR, appears to re-create a vibrant and never-ending debate on the private law nature of the employer who does not implement the principle of freedom of contract when concluding a contract of employment. Because it is simply an entity pursuing public interests. The social labour inspector is a prototype of data protection officer in the field of labour law. As a matter of fact, he is also executing this "dispersed" public authority in labour law. Thus, the topic of "dispersed" public authority taken up by Arkadiusz Sobczyk brilliantly reflects the "spirit" of a long-lasting problem with 
systemic classification of the labour law. The Author offers another "portion" of arguments about the importance of the impact of public administration on the sphere of employment relationships and personal data, which makes both labour law and personal data protection law another divisions of administrative law in the scope where the state performs its public tasks. And that is what I find to be the greatest value of the discussed monograph, guided by an urgent need to finally lay a firm theoretical foundation for labour law. Without it, the milieu of law practitioners is unable to handle increasingly complex facts.

\section{References}

Bosek L. (2016) [in:] M. Safjan, L. Bosek (eds.), Konstytucja RP, t. 1: Komentarz do art. 1-86, Warszawa.

Drozd E. (1990) Numerus clausus praw rzeczowych [in:] S. Sołtysiński (ed.), Problemy kodyfikacji prawa cywilnego (studia i rozprawy), Ksiega pamiątkowa ku czci professora Zbigniewa Radwańskiego. Praca zbiorowa, Poznań.

Niedośpiał M. (2004) Swoboda czynności prawnych, Bielsko-Biała.

Niżnik-Dobosz I. (2017) Wolność w prawie administracyjnym, Warszawa.

Skowrońska-Bocian E. (2003) Prawo spadkowe, Warszawa.

Sobczyk A. (2019) RODO. Rozproszona władza publiczna, Kraków.

Wild M. (2016) [in:] M. Safjan, L. Bosek (eds.), Konstytucja RP, t. 1: Komentarz do art. 1-86, Warszawa. 